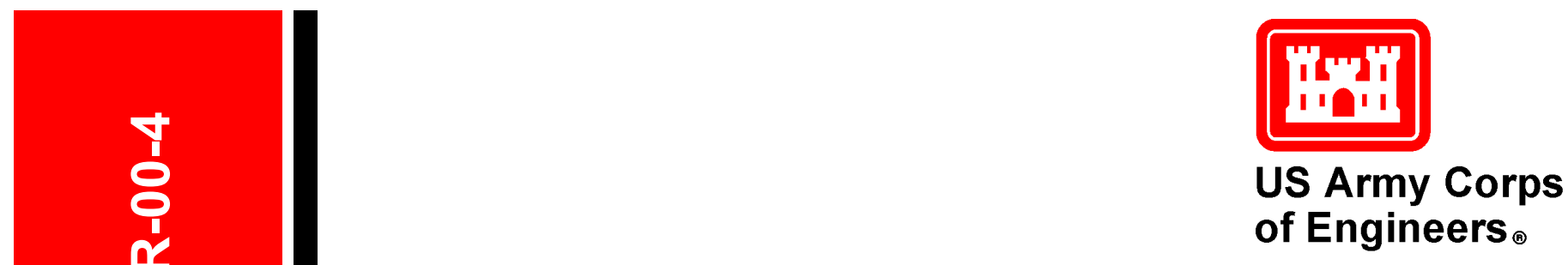

Installation Restoration Research Program

Procedures for Determining Integrity of UXO and Explosives Soil Contamination at Firing Ranges

James M. Brannon, Thomas F. Jenkins, Louise V. Parker, July 2000 Patrick Deliman, Jeffrey A. Gerald, Carlos Ruiz, Beth Porter, and William M. Davis 
The contents of this report are not to be used for advertising, publication, or promotional purposes. Citation of trade names does not constitute an of ficial endorsement or approval of the use of such commercial products.

The findings of this report are not to be construed as an official Department of the Army position, unless so designated by other authorized documents . 


\section{Procedures for Determining Integrity of UXO and Explosives Soil Contamination at Firing Ranges}

by James M. Brannon, Patrick Deliman, Carlos Ruiz, William M. Davis

Environmental Laboratory

U.S. Army Engineer Research and Development Center 3909 Halls Ferry Road

Vicksburg, MS 39180-6199

Thomas F. Jenkins, Louise V. Parker

Cold Regions Research and Engineering Laboratory

U.S. Army Engineer Research and Development Center 72 Lyme Road

Hanover, NH 03755-1290

Jeffrey A. Gerald, Beth Porter

ASCI Corporation

1365 Beverly Road

McLean, VA 22101

Final report

Approved for public release; distribution is unlimited. 


\section{Engineer Research and Development Center Cataloging-in-Publication Data}

Procedures for determining integrity of UXO and explosives soil contamination at firing ranges / by James M. Brannon ... [et al.] ; prepared for Headquarters, U.S. Army Corps of Engineers.

37 p. : ill. ; 28 cm. -- (ERDC ; TR-00-4)

Includes bibliographic references.

1. Soil pollution. 2. Explosives -- Environmental aspects. 3. Rifle-ranges -- Environmental aspects.

I. Brannon, James M. II. United States. Army. Corps of Engineers. III. Engineer Research and Development Center (U.S.) IV. Environmental Laboratory (U.S.) V. Cold Regions Research and Development Laboratory (U.S.) VI. Series: ERDC TR ; 00-4.

TA7 E8 no.ERDC TR-00-4 


\section{Contents}

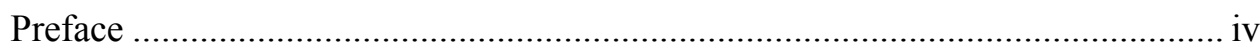

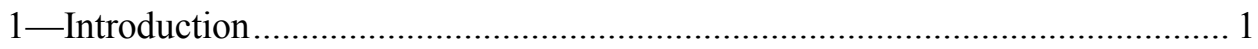

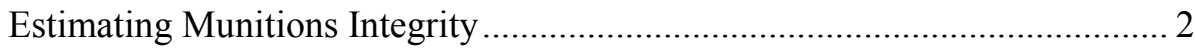

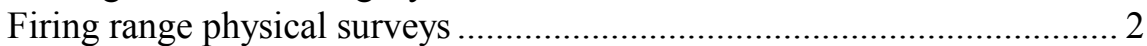

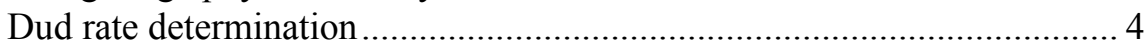

Low-order detonations....................................................................... 5

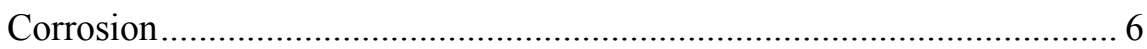

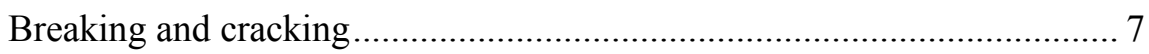

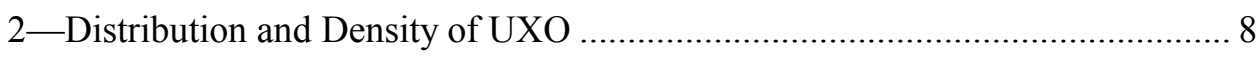

3-Range Sampling Protocol for Estimating the Concentrations

of Explosives Residues in Soils .................................................................. 9

Results of Previous Sampling Studies .......................................................... 9

Protocol for Soil Sampling, Compositing, and Onsite Analysis .................... 11

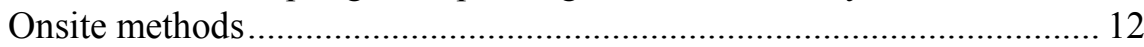

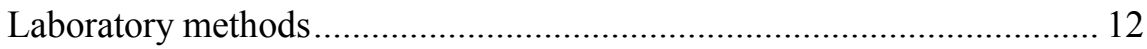

4-Sampling and Analysis of Surface Soils at an Artillery and Mortar

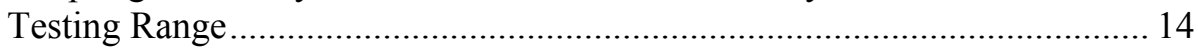

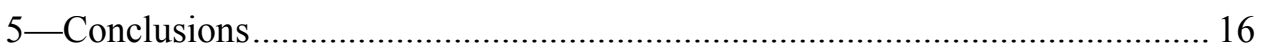

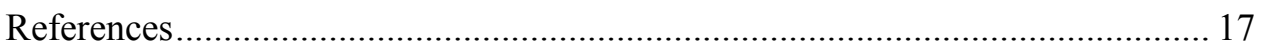

Appendix A: Assessment of Fort Ord Data................................................. A1

Appendix B: Composition of Common Munitions ……....................................

Appendix C: Effects of Steel on Soluble TNT, RDX, and HMX ........................ 1 


\section{Preface}

The work reported herein was conducted by the U.S. Army Engineer Research and Development Center (ERDC), Environmental Laboratory (EL), Vicksburg, MS, for Headquarters, U.S. Army Corps of Engineers (HQUSACE). Funding was provided by the HQUSACE Installation Restoration Research Program (IRRP), Fate \& Effects Thrust Area; Work Unit entitled Fate and Transport of Unexploded Ordinance (UXO). Dr. Clem Myer was the IRRP Coordinator at the Directorate of Research and Development, HQUSACE. The IRRP Program Manager was Dr. M. John Cullinane, ERDC, EL.

This report was prepared by Drs. James M. Brannon and William M. Davis, Ecosystem Processes and Effects Branch (EPEB), Environmental Processes and Effects Division (EPED), EL, ERDC; Patrick N. Deliman and Carlos E. Ruiz, Water Quality and Contaminant Modeling Branch (WQCMB), EL, ERDC; Thomas F. Jenkins and Ms. Louise V. Parker, Geological Sciences Division, Research and Engineering Directorate, Cold Regions Research and Engineering Laboratory, ERDC; and Ms. Beth Porter and Mr. Jeffrey A. Gerald, ASCI Corporation, McLean, VA. Drs. Judith C. Pennington, EPEB, EPED, EL, and Mark S. Dortch, WQCMB, EPED, were technical reviewers for this report.

The authors would like to acknowledge Mssrs. Patrick Reanier, USA Environmental, Geographical Information System Manager; Douglas Ralston, CMS Project Manager; Michael Coon, USA Environmental, QC Specialist; Major Darren Rodeschin, Ordinance and Explosives Project Manager at Fort Ord, California; and Mr. John Esparza, U.S. Army Engineer District, Sacramento, for providing the data set of recovered UXO items at Fort Ord.

The authors also acknowledge the assistance of Mr. Joseph Bucci, Maryland Environmental Technologies Demonstration Center (METDC), Aberdeen Test Center, Aberdeen Proving Ground, Maryland, for providing access to an artillery firing range and assisting in the collection of soil samples near UXO items for preliminary characterization.

The work was conducted under the general supervision of Dr. Richard E. Price, Chief, EPED, and Dr. John Keeley, Acting Director, EL, ERDC.

At the time of publication of this report, Dr. James R. Houston was Director of ERDC, and COL James S. Weller, EN, was Commander. 
This report should be cited as follows:

Brannon, J. M., Jenkins, T. F., Parker, L. V., Deliman, P. N., Gerald, J. A., Ruiz, C. E., Porter, B., and Davis, W. M. (2000). "Procedures for Determining Integrity of UXO at Firing Ranges," ERDC TR-00-4, U.S. Army Engineer Research and Development Center, Vicksburg, MS. 


\section{Introduction}

Unexploded Ordnance (UXO) is military munitions that have been prepared for action, fired, dropped, or buried, and remain undetonated, posing a hazard to operations, personnel, or material. The 1997 UXO Clearance Report to Congress estimates that millions of square meters (acres) throughout the United States, including 1,900 Formerly Used Defense Sites (FUDS) and 130 Base Realignment and Closure (BRAC) installations, potentially contain UXO. Implementation of the "Range Rule," which will identify the process for evaluating appropriate response actions on Closed, Transferred, and Transferring Military Ranges, will potentially add millions of additional acres to the Army's UXO cleanup liability.

A relatively large body of information exists on explosives concentrations at sites impacted by manufacturing operations (Walsh et al. 1993), but much less information is available on explosives concentrations from UXO at firing ranges. Jenkins et al. (1997a,b, 1998) studied the concentrations of explosives residues in surface soils at two antitank firing ranges; the first at an operational firing range at Canadian Force Base Valcartier, Quebec, and the second at a closed range at Fort Ord, California. In both cases the major contaminant found was HMX at concentrations as high as $1,900 \mathrm{mg} / \mathrm{kg}$ at Valcartier and $587 \mathrm{mg} / \mathrm{kg}$ at Fort Ord. The reason for these high concentrations at both ranges appeared to be the presence of ruptured, but undetonated, light antiarmor weapons (LAW rockets) at each site. No similar data were found for other types of firing ranges.

Fate and transport of explosives from UXO have been identified as a high priority user requirement and as an important emerging need during promulgation of the "Range Rule." Limited research has been conducted in this area; therefore, processes controlling the fate and transport of explosives from UXO are poorly understood. Once explosives from UXO move beyond the confines of the delivery system (mortar shell, artillery shell, rocket, etc.), the processes affecting fate and transport should be similar to those associated with explosives contamination from other sources (Brannon and Myers 1997; Townsend and Myers 1996; McGrath 1995). The primary difference between the fate and transport of UXO explosives and transport of explosives from disposal of contamination associated with loading, assembling, or packing is the integrity of the UXO delivery system and the greater heterogeneity in the firing range soil. The objective of this report is to present methods for determining the integrity and distribution of UXO on firing ranges and concentrations of explosives around UXO. 


\section{Estimating Munitions Integrity}

The goal is to estimate the amount of explosives that can adversely affect the environment and that can contribute to UXO chemical signatures. The physical condition of the UXO has a pronounced effect not only on potential environmental impacts but also on chemical signatures that contribute to localization and discrimination of the UXO. Munitions at firing ranges can exist in two physical conditions. Intact delivery systems may contribute negligible amounts of explosives to the environment. However, over time, corrosion may occur and pinhole cracks may develop in the munitions leading to loss of explosives. Leakage may also occur through screw threads linking the fuse assembly to the main charge in UXO submerged in water (Darrach, Chutfion, and Plett 1998). Low-order detonation or breakup of the delivery system without detonation may also occur, leading to the survival of part or all of the explosive. The explosive may be scattered over the firing range as free product or partially encased in the remains of the delivery system. Both conditions can lead to immediate explosives contamination of soils and can serve as a continuous source of contamination.

Estimation of explosives concentrations in firing range soils involves sampling at the firing range and requires information on UXO integrity at firing ranges in conjunction with soil sampling. Prior to conducting human health and ecological risk assessments for explosives, a risk assessment for explosive safety will be conducted in almost all cases. To estimate potential ordnance exposures, surface and subsurface ordnance densities and the distribution of ordnance with depth are estimated. If cleanup has been conducted on a firing range, fate and transport determinations will be more accurate if explosives concentrations in the soil are measured. In the absence of field information, many of the assumptions used in conducting initial evaluations of integrity and distribution will be inaccurate to some extent. Therefore, estimates must be revised as additional data on condition and distribution of munitions and concentrations of explosives in the soil are obtained. Revised estimates can result in a more accurate determination of potential environmental impacts and impacts of future firing activities.

\section{Firing range physical surveys}

Information on the integrity of UXO at firing ranges has not generally been gathered during clearing operations (Fauth 1988). The following is a summary of observations presented by Fauth:

a. At one bombing range, over 56 percent of the surface UXO was in the aim point grid.

$b$. At one bombing range, no ordnance with high explosive (HE) filler was found. All ordnance was inert. Inert rounds that contain nonexplosive filler material in place of $\mathrm{HE}$ and a spotting charge and fuze are often used in training. 
c. The condition of UXO on a single site can vary widely, ranging from near perfect condition to barely recognizable.

d. Experience with German bombs in the ground for over 20 years showed that the steel structure of the bomb bases did not rust extensively.

However, corrosion rates may be entirely different in surface environments.

e. Cast fillings appear to age better than powder fillings. Powder fillings were always found in a seriously deteriorated condition while cast fillings showed no serious signs of deterioration. Cast fillings are generally used in U.S. munitions

Range clearance operations generally result in recovery and identification of a wide variety of munitions, both modern and obsolete (Table 1). Twenty general categories of munitions were recovered at one Fort Ord firing range. Each of these can contain numerous specific types of munitions, multiple explosives in various quantities, as well as propellants and/or other additives (Appendix A). Information on the explosives content of many obsolete munitions are not readily available (Appendix B).

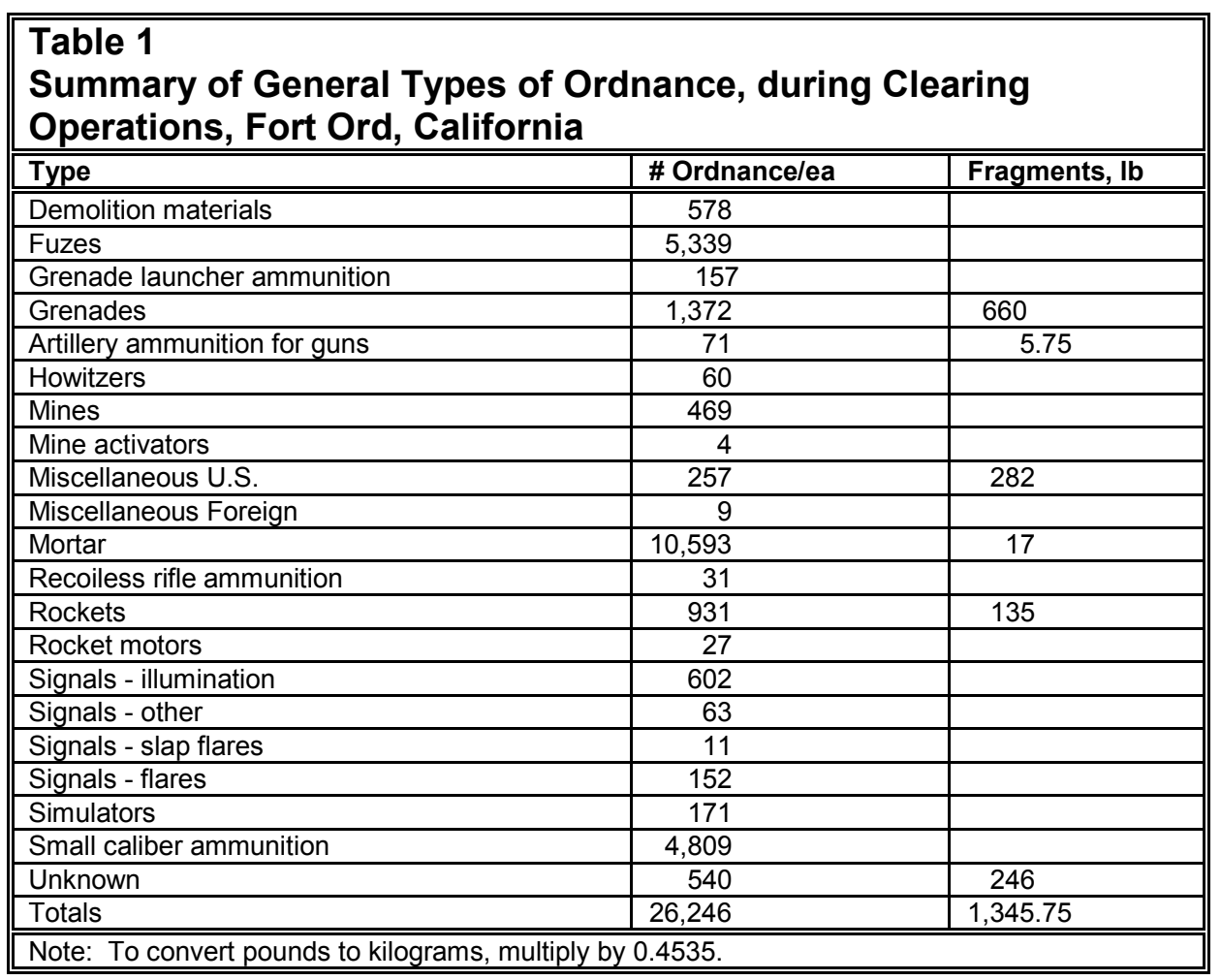

The dangers inherent at firing ranges limit the involvement of researchers in surveying the condition of munitions. Surveys of munitions integrity must be conducted by trained explosive ordnance demolition (EOD) personnel, typically during range cleanups. These safety requirements reduce the number of available 
sites and require cooperation by organizations and personnel, with the primary mission being to safely clear the range of UXO.

UXO and soil explosives data for firing ranges can be expected to be highly variable, ranging from sites with extensive characterization to those for which limited information exists. At sites that have been extensively characterized, soil explosives data may be available to provide the basis for predicting the potential environmental impacts of range activities. At firing ranges for which no soil concentration data exist, estimates of munitions number, integrity, and distribution must be extrapolated from firing range history. Estimates can then be used to determine if potential environmental impacts necessitate immediate cleanup, if a lower priority can be assigned, or if periodic cleanup will be needed on active ranges.

\section{Dud rate determination}

Firing range histories, when available, permit an estimate of the number and types of munitions fired (Figure 1). The histories can be used in two ways to estimate the number of UXO of each type on a particular firing range. If observer records are available for the site, an actual count of the number of rounds of each type that did not explode may be available. Where such records do not exist or more rapid evaluation is needed, estimates of the number of UXO can be based on the total number of rounds of each type fired. Firing range records can be expected to vary widely in quality. Records for many sites, especially for the World War II time period, are often poor. Determining exactly how many munitions of a particular type were fired at a range can be difficult. Estimation and interpolation from existing firing records in conjunction with information from the risk assessment for range ordnance safety will be needed. Firing range histories and dud rates for munitions may be used during the explosives safety risk assessment. If so, such data will be available for the ecological and human health risk assessments. Regardless of where in the process the estimate of UXO is made, dud rates for a wide variety of munitions are required.

Information on munitions dud rates allows the total number of UXO on a firing range to be estimated (Figure 1). Data are available on dud rates for some types of munitions. Conley et al. (1997) conducted a firing records search of 75-, 105-, and 155-mm caliber weapons testing at Aberdeen Proving Ground (APG), MD. The firing records search revealed a total of 98,849 firing records covering 2.34 million rounds fired from 1918 to 1997 . Results showed that dud rates based on observer records (remaining rounds/fired rounds x 100 percent) were 3.6 percent for $75-\mathrm{mm}, 6.9$ percent for $105-\mathrm{mm}$, and 4.7 percent for $55-\mathrm{mm}$ munitions. Because of the wide variety of artillery types and munitions used over the 79-year period of the study, these rates are average values useful for screening level evaluations. Dud rates for M72 LAW rockets on the order of 50 percent were noted at Canadian firing ranges (Thiboutot et al. 1998). Estimated dud rates for other types of munitions are not presently available. The Defense Ammunition Center, McAlester, OK, is conducting a study to provide accurate estimates of low-order detonation and dud rates for large caliber munitions (Owens 1999). 


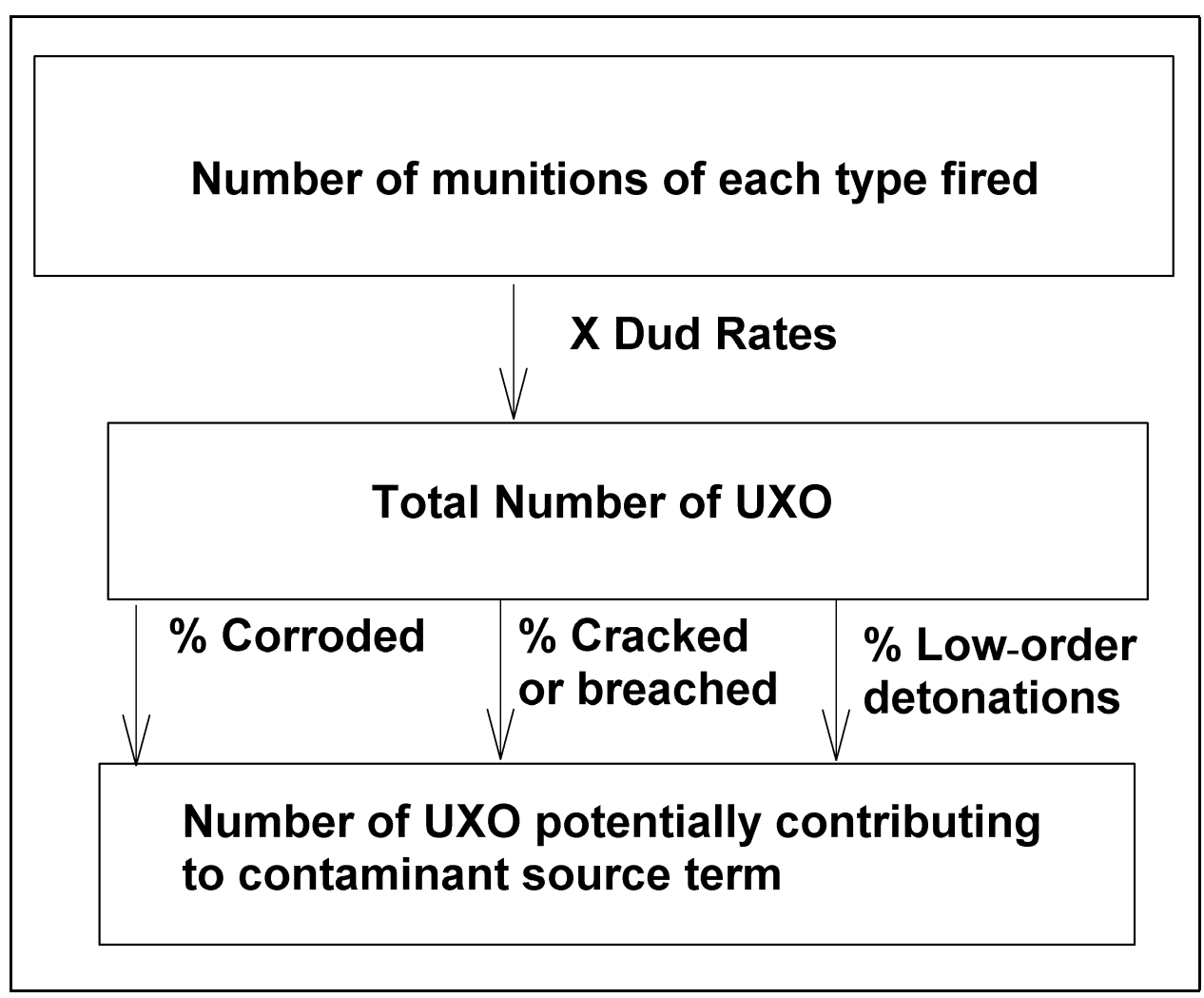

Figure 1. Procedures for estimating the integrity of UXO on a firing range

\section{Low-order detonations}

Information on UXO resulting from low-order detonations is limited. Fauth (1988) reported that the Mk 80 series bombs recovered at Range B-20, Naval Air Station, Fallon, NV, were generally in good condition with a small percentage (less than 5 percent) of bombs undergoing low-order detonations split open and exposing HE filler. Estimates of low-order rates from munitions test firing records are presently being determined by the Defense Ammunition Center (Owens 1999).

Range clearance records from Fort Drum, New York, show only three loworder detonations, two for mortars and one for artillery (Table 2). The total number of munitions (eight) of the types for which low-order detonations were reported were insufficient to provide statistically valid estimates of low-order rates. Additional range clearance data will increase the sample size and provide estimates of low-order rates for some munitions.

Determination of low-order detonation rates from observations during range clearance may be difficult if a large number of inert rounds with live fuses were fired during training. For example, inert rounds constituted over 71 percent of the rounds fired at APG, with a sizeable percentage containing live fuses (10.5 percent). Dud rates for the inert rounds with live fuses were 11 percent for $75-\mathrm{mm}, 7$ percent for $105-\mathrm{mm}$, and 9 percent for $155-\mathrm{mm}$ munitions. When the 


\begin{tabular}{|c|c|c|c|c|}
\hline Munition & "Number Recovered & Condition & Percent Breached & Percent Low-Order \\
\hline 40-mm HE grenade & 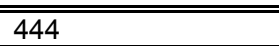 & "armed & $\overline{0}$ & 0 \\
\hline 40-mm Smoke grenade & 206 & armed & 0 & 0 \\
\hline 40-mm practice $\mathrm{w} / \mathrm{HE}$ & 33 & armed & 0 & 0 \\
\hline 3.5-in. Rocket, HEAT & 21 & armed & 0 & 0 \\
\hline 76-mm HE & 13 & 2 fuses broken & 15 & 0 \\
\hline 40-mm Illumination & 10 & armed & 0 & 0 \\
\hline 2.36-in. Rocket, HE & 9 & armed & 0 & 0 \\
\hline 60-mm HE Mortar & 3 & 1 low-order & 0 & 33 \\
\hline 81-mm WP Mortar & 3 & 1 partial fuse, 1 low-order & 33 & 33 \\
\hline 4.2-in. HE Mortar & $\frac{2}{2}$ & armed & 0 & 0 \\
\hline 81-mm Illumination Mortar & 2 & armed & 0 & 0 \\
\hline 105-mm HE Artillery & 2 & 1 low-order & 0 & 50 \\
\hline 106-mm HEAT & 1 & armed & 0 & 0 \\
\hline 4.2-in. Illumination Mortar & 1 & armed & 0 & 0 \\
\hline
\end{tabular}

fuses function, a partial projectile remains, losing either the nose/ogive (the curved nose of a projectile) of the projectile or the base in the case of a base fuse. Because of the widespread use of inert training rounds at firing ranges (Fauth 1988), partial inert rounds resulting from fuse function could be confused with rounds containing HE that have undergone low-order detonation. This may result in overestimating the percentage of low-order detonations and the amount of explosives in the environment. Range surveys for munitions that have undergone incomplete detonation will therefore need to focus on identifiable HE rounds. Low-order detonations should be identifiable by the fact that major portions of the munitions casing remain intact even though it may be twisted and burned. Proper detonation of HE in munitions (other than in some shaped charges) is designed to produce fragmentation of the munitions casing.

\section{Corrosion}

Corrosion is a complex process for which rates vary as a function of the presence and activities of microorganisms, which is in turn influenced by environmental conditions (McNeil and Odom 1992). As pointed out in the literature review by Fauth (1988), steel casings in the ground do not appear to rust extensively. Surface UXO are likely to behave differently. The U.S. Army Aberdeen Test Center, Maryland, is developing a model to determine the degradation of UXO in soils from corrosion under various conditions of redox potential, soil moisture, and $\mathrm{pH}$ (Owens 1999). Transport of explosives from corroded UXO is a more complex process than flux of explosive from the main charge through pinhole perforations in the munitions casing. Corrosion of steel casings will produce a complex local environment comprising intact steel and iron oxidation, as well as reduction products through which the explosives must pass to exit the munition and enter the environment. The impact of common steel on 2,4,6-trinitrotoluene (TNT), hexahydro-1,3,5-trinitro-1,3,5-triozine (RDX), and octahydro-1,3,5,7-tetranitro-1,3,5,7-tetrazocine (HMX) solution concentrations are presented in Appendix C. 


\section{Breaking and cracking}

Limited information is presently available on breaking and cracking of munitions. The high dud rate observed for M72 LAW rockets resulted in many of the munitions' breaking upon hitting targets or rocks, exposing the octol (70 percent TNT:30 percent HMX) to the environment (Thiboutot et al. 1998). For these and other direct fire munitions, the rate of cracking and breakage can be expected to be higher than for artillery and mortar munitions which have stronger casings and impact the range at a greater angle. The data available on various types of munitions support this expectation. Two broken fuses, probably from direct fire recoilless rifles, were found among thirteen 76-mm HE munitions (Table 2). Anecdotal evidence also suggests that mortar munitions are more susceptible to cracking upon impact than artillery munitions. One partially fused mortar, denoting breakage upon impact, was found among eleven total mortar munitions of various sizes recovered at Ft. Drum (Table 2). Examination of 70- and 127-m (2.75- and 5-in.) rockets at Range B-20, Naval Air Station, Fallon, $\mathrm{NV}$, showed that the rocket warheads were in good condition, but the rocket motors were in poor condition exposing propellant to the environment. A small percentage $(<5$ percent) of practice bombs with inert fillers were split open at the range, but the exact percentage was not given (Fauth 1988).

Any evaluation of cracking and breakage of munitions that follows must necessarily be conducted by the EOD personnel during clearing operations. Many munitions are unstable and must be destroyed in place (Fauth 1988). This means that the general condition of the breakage or cracking or other deterioration must be noted prior to destruction. An example of the type of information that should be gathered is presented in Table 3. This type of information can be gathered during clearing. Information on cracking and breakage is not dependent on whether the munition contains HE or is an inert round. The entire sample of fired munitions (HE + Inert) can be used to estimate percentage breakage and cracking of a particular munition.

\begin{tabular}{|c|c|}
\hline \multicolumn{2}{|c|}{$\begin{array}{l}\text { Table } 3 \\
\text { Suggested Additional Information on Munition Integrity During Firing Range Cleanup } \\
\text { (This information should be gathered for each individual munition as appropriate) }\end{array}$} \\
\hline Information Gathered & Examples \\
\hline \multicolumn{2}{|l|}{ Munition identification } \\
\hline Type of round & 40-mm HE grenade \\
\hline Nomenclature (if known) & M223, etc \\
\hline Is round fuzed? & Yes/no and fuze type if known \\
\hline Explosive filler & TNT, octol, etc. \\
\hline Inert round & AP, Expended, practice \\
\hline Type of round & 105-mm APFSDS (armor piercing fin stabilized discarding sabot \\
\hline Nomenclature (if known) & M103 \\
\hline Large segment of round from low-order detonation & Dimensions (length and width) \\
\hline Type of round & $155-\mathrm{mm} \mathrm{HE}$ \\
\hline Nomenclature (if known) & M106 \\
\hline \multicolumn{2}{|l|}{ Condition of munition } \\
\hline Corrosion status & Good condition, slightly corroded, heavily corroded \\
\hline Structural integrity & $\begin{array}{l}\text { Cracked open, length of crack } 25.4 \mathrm{~cm} \text { (10 in.), filler leaking out, } \\
\text { explosive residue surrounding round }\end{array}$ \\
\hline
\end{tabular}




\section{Distribution and Density of UXO}

Determining the distribution and density of UXO on a firing range is a difficult exercise. Over the years, targets may have been moved numerous times, munitions types changed, and firing points and firing objectives changed. This can result in unexpected and unpredictable UXO distribution patterns that will complicate exposure assessments for both explosives safety and human and environmental impacts. The estimates of ordnance density and distribution obtained during the explosives safety exposure assessment will be an important tool for estimating human and ecological exposures. This is especially true if the projected distribution and density have been verified and refined by sampling of some of the sectors set up to study the firing range.

One tool that can be used to estimate UXO density is the Unexploded Ordnance Density Calculator developed for U.S. Army Corps of Engineers Engineering and Support Activity, Huntsville, AL. The UXO calculator uses a negative binomial distribution to predict the probability of finding UXO in a particular sector. The UXO calculator is especially effective when coupled with a sampling program because it allows estimates to be refined. The grid setup and ordnance densities in the various grids can also be varied, allowing site specific distribution patterns to be modeled. The distribution and density for a firing range can then be used as input into human health and ecological exposure assessment models.

The Army Fate \& Effects Research Program is developing the Army Risk Assessment Modeling System (ARAMS) to perform risk assessment at military facilities. ARAMS is a comprehensive system employing the Framework for Risk Analysis in Multimedia Environmental Systems (FRAMES) to perform human and ecological risk assessment for a variety of sources including target ranges. Target ranges could be modeled through the integration of the Unexploded Ordinance Density Calculator into the FRAMES modeling platform. The density calculator would provide the location and density of UXO. The source term module (Brannon et al. 1999) and FRAMES would be utilized to provide information relating the fate and transport of UXO explosives through the environment. FRAMES was developed by the Department of Energy Pacific Northwest National Laboratory (DOE-PNL) in cooperation with the U.S. Environmental Protection Agency (USEPA) by Battelle Memorial Institute and is consistent with EPA guidance with regard to conducting site risk assessments. 


\section{Range Sampling Protocol for Estimating the Concentrations of Explosives Residues in Soils}

\section{Results of Previous Sampling Studies}

To evaluate the need for remediation, site characterization is conducted to determine the concentration of contaminants of concern in soil and water. Potentially contaminated sites are traditionally divided into small geographically defined units (grids), and samples are collected and analyzed to estimate the mean concentrations of contaminants within these grids. The dimensions of these grids can range from tens of meters (feet) to hundreds of meters (feet) on a side. To characterize a grid, a single core sample has often been collected within the grid, divided into depth intervals, and the samples analyzed at offsite commercial laboratories. Comparing contaminant concentrations obtained from the analysis of these samples to action levels determined by risk assessment are used to decide the need for cleanup.

This sampling approach assumes that the concentration of contaminants of interest in discrete samples adequately represents the average concentration of those contaminants at the collected depths within grid boundaries. This assumption was first evaluated at seven TNT-contaminated sites on three installations that were contaminated during explosives manufacturing operations (Jenkins et al. 1997a). The results indicated that enormous short-range spatial heterogeneity in TNT concentration existed at each site and that the total error in characterization was dominated by sampling error. However, sampling error was significantly reduced through the use of composite samples.

A second study was conducted at an active antitank firing range at Canadian Force Base Valcartier (Jenkins et al. 1997b). This range was exclusively used for troop practice using the 66-mm M72 light antiarmor weapon (LAW rockets)

(Figure 2). The explosive charge in these rockets is octol which is composed of a 70:30 ratio of HMX and TNT. Results of this study demonstrated that HMX had 


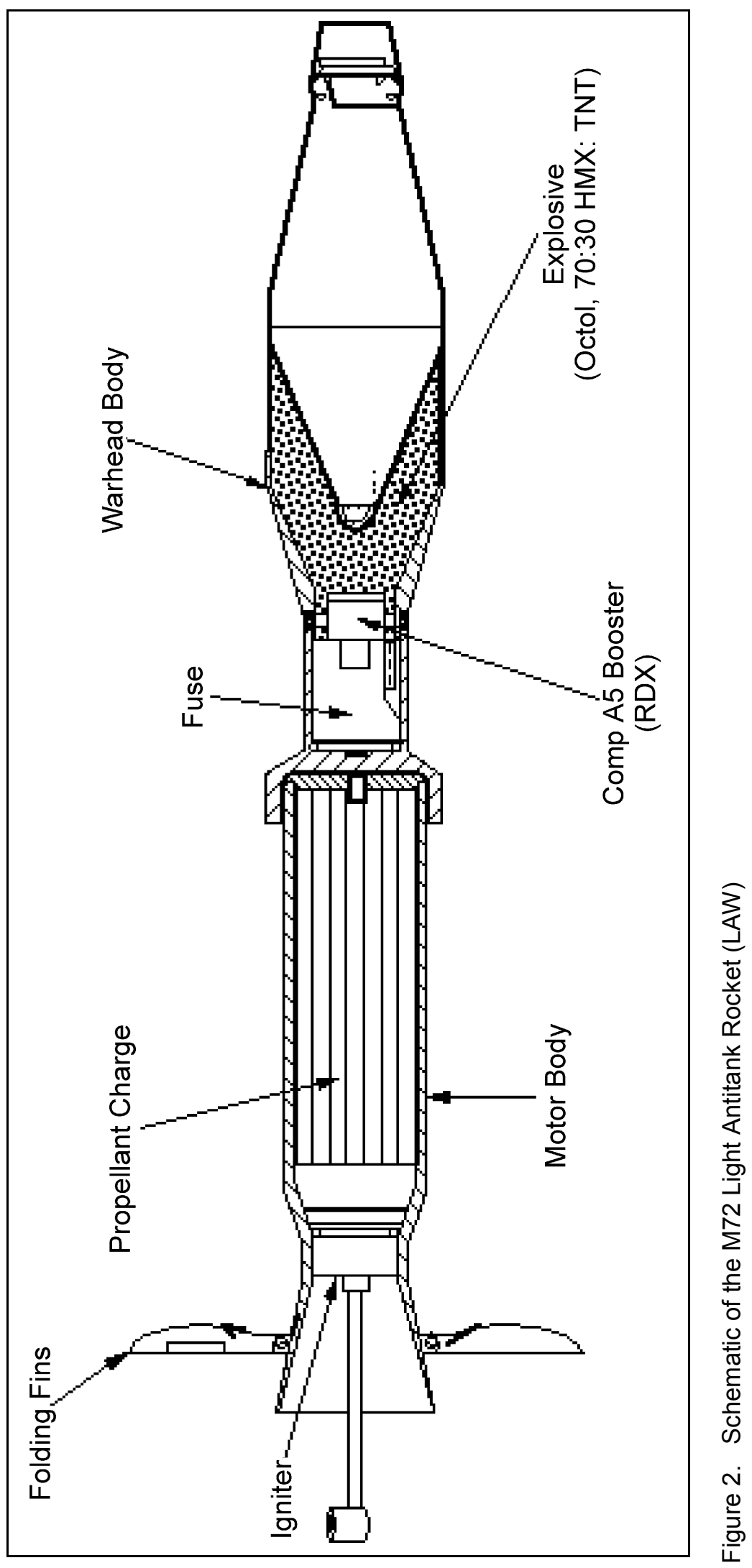


accumulated in near-surface soils ( 0 to $5 \mathrm{~cm}$ ) at concentrations as high as $1,900 \mathrm{mg} / \mathrm{kg}$ near tank targets, but TNT concentrations were only about onehundredth as high. As observed at the sites contaminated during manufacturing operations, spatial heterogeneity of HMX concentrations was very large, making it impossible to obtain reliable estimates of mean concentrations using discrete samples. Here again, the use of composite samples greatly reduced sampling error.

The results at Valcartier were confirmed by a third study at an antitank firing range at Fort Ord, California (Jenkins et al. 1998). This was a closed (BRAC) range that had been used predominantly for troop practice with M72 LAW rockets and mortars but had not been used for several years prior to sample collection. At Fort Ord, the near-surface soils $(0$ to $15 \mathrm{~cm})$ at locations in close proximity to tank targets were contaminated with HMX at about the same levels found at Valcartier. Concentrations of TNT and other explosives residues in these near-surface soils were very low as were concentrations of all residues including HMX at depths below $15 \mathrm{~cm}$. Spatial heterogeneity of HMX concentrations was very large at the Fort Ord site, but when composite samples were used, a pattern of concentration dependence on distance from the target was revealed. The high concentrations of HMX at Valcartier and Fort Ord seemed too high to be due to residues from detonations and probably resulted from rupture of unexploded rockets and ejection of explosives particulates. The much lower accumulation of TNT in these soils is probably a result of the rapid biotransformation of TNT to amino-dinitrotoluenes (DNTs).

Explosives represent a fairly unique set of environmental contaminants. Most explosives and impurities that make up these residues (TNT, RDX, HMX, tetryl, 2,4-DNT) are solids at environmental temperatures and are generally released into the environment as particulates. The particulate nature of these contaminants leads to accumulation in near-surface soils and substantial spatial heterogeneity. Because these compounds have low-vapor pressures, no special precautions to mitigate vapor losses are needed during sample collection and compositing. These explosives are relatively polar, particularly for neutral organic compounds, and do not sorb strongly to soils by hydrophobic interactions. The major explosives contaminants have aqueous solubilities ranging from 5 to $150 \mathrm{mg} / \mathrm{L}$ and dissolve very slowly in aqueous solution. Because of these factors, high concentrations of explosives can persist in surface soils for decades. However, once dissolved in water, explosives contaminants can migrate rapidly through the unsaturated zone to the aquifer. Therefore, delineation of the concentrations of explosives residues in near surface soils is necessary to determine if remediation is needed to mitigate the potential for groundwater contamination.

\section{Protocol for Soil Sampling, Compositing, and Onsite Analysis}

To estimate the mean concentration of explosives residues in surface soil in geographically defined grids, sampling must be as representative as possible. To 
provide representative samples, a set of discrete soil cores in the 0 - to $15-\mathrm{cm}$ depth range is collected from random positions within the grid. The number of discrete samples are a function of the size of the grid and the variance of concentration estimates obtained from preliminary samples collected within the area.

Each discrete sample is homogenized onsite by placing the material in a disposable aluminum pan and breaking up the soil into fine particles using gloved hands. The processed material is mixed thoroughly. An equal mass of each discrete sample from within the grid is placed in an aluminum pan. This grid composite sample is further homogenized, then coned and quartered to provide the mass of subsample required for the onsite and laboratory methods. In at least 10 percent of the grids sampled, a second set of discrete samples (duplicates) is collected and used to prepare a second composite sample in the same manner as just described. Comparison of the sets of duplicate composites provides estimates of the total error in site characterization.

\section{Onsite methods}

Two methods are used for onsite assessment of the concentration of explosives residues in soils. The first is the colorimetric methods for TNT and RDX/HMX currently marketed by Strategic Diagnostics Incorporated (SW846 Methods 8515 and 8510). These methods provide precise and accurate characterization of TNT and HMX concentrations for soils from ammunition plants and firing ranges (Jenkins et al. 1997a; 1998; 1999). A comparison of the concentrations estimates for HMX using the colorimetric method with those from Method 8330 for soils from the Valcartier antitank range agreed very well (Figure 3). These relatively inexpensive, rapid tests are used in preliminary testing to estimate site heterogeneity and explosives distribution.

In addition, a new GC-NPD method can be used onsite to analyze firing range soil residues (Hewitt and Jenkins 1999). This method provides lower detection limits than either the colorometric methods or the standard analytical procedure (SW846 Method 8330 (USEPA 1994)). Furthermore, the method measures the suite of analytes often present on explosives-contaminated sites in a single analysis. In particular, this method allows for the characterization of TNT, RDX, 2,4-dinitortoluene (2,4-DNT), 4-aminoditnirotoluene (4-ADNT), and 2-aminodinitrotoluene (2-ADNT) in a single determination.

\section{Laboratory methods}

Low levels of many explosives contaminants are anticipated on many firing ranges. Therefore, soil samples should be analyzed in the laboratory by a new GC-ECD method (Walsh and Ranney 1999). This method has been given preliminary approval by the Organics Work Group of EPA's Office of Solid Waste as SW846 Method 8095. Method 8095 uses the extraction procedure described in Method 8330 (USEPA 1994) followed by analysis of the acetonitrile extracts by gas chromatography with an electron capture detector (GC-ECD). 


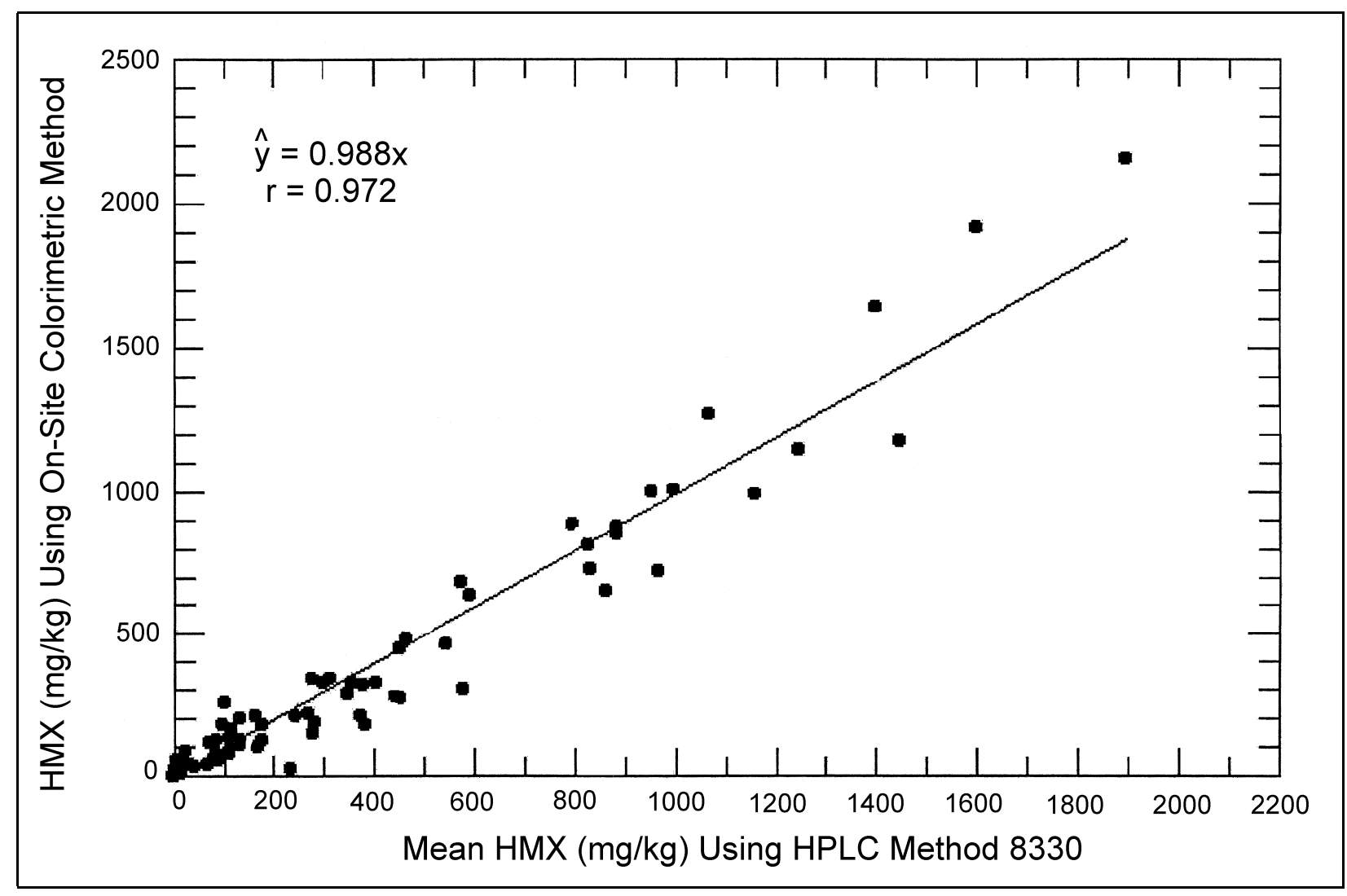

Figure 3. Relationship between the onsite colorimetric method and HPLC method for HMX

This method provides detection limits about 250 times lower than Method 8330 (USEPA 1994), especially for TNT and 2,4-DNT (detection limits are less than $1 \mu \mathrm{g} / \mathrm{kg}$ ). These lower detection limits will probably be needed on some types of ranges where the low-order detonation rates of the munitions are very low and the detonations are near complete with respect to destruction of the enclosed explosive charges. 


\section{Sampling and Analysis of Surface Soils at an Artillery and Mortar Testing Range}

Very little information is currently available on the concentrations of explosives residues at testing and training ranges. In particular, the levels of residues associated with active artillery and mortar ranges are poorly understood.

To provide an initial evaluation, a series of 16 surface soil samples were collected in a forested environment at an active artillery and mortar testing range. Samples were collected using a small garden shovel from the following locations; (a) next to unexploded $155-\mathrm{mm}$ projectiles; (b) in craters where initially unexploded projectiles had been detonated with composition C4; (c) next to a previously undetonated 155 -mm-high explosive (HE) filled projectile that had undergone a low-order detonation when an attempt was made to detonate it with $\mathrm{C} 4$; (d) in craters caused by the detonation of an 81-mm mortar with $\mathrm{C} 4$; (e) next to a crater caused by the detonation of a $60-\mathrm{mm}$ trench mortar with $\mathrm{C} 4$, and (f) in an area with no craters or other apparent UXO items but within $8 \mathrm{~m}$ $(25 \mathrm{ft})$ of other detonation craters. The last samples were collected to determine if a general level of contamination existed across the range. Soil samples were analyzed for explosives contaminants using the new GC-ECD method described previously (Walsh and Ranney 1999). In no case was RDX detected in any soil samples (Table 4). This indicates that no residues remained from the $\mathrm{C} 4$ used to detonate these munitions. In addition, no RDX was found in the soil next to the low-order detonation. Apparently, the low-order 155-mm round was not filled with Composition B, but with TNT.

TNT was detected in two of the four soil samples collected next to two unexploded 155-mm artillery projectiles (sampling locales 1 and 2). The TNT values varied by two orders of magnitude in the samples collected on opposite sides of the projectile in locale 1 . These results emphasize the high degree of heterogeneity on firing ranges.

Explosives in the four soils collected in 155-mm detonation craters (locales 3 and 4) were at very low concentrations (Table 4). TNT was present at the highest concentration, but the maximum value found was $3.8 \mathrm{mg} / \mathrm{kg}$. Compared with the concentrations found at soils from ammunition plants and depots, these concentrations are very low (Walsh et al. 1993). 


\begin{tabular}{|c|c|c|c|c|c|c|c|}
\hline \multicolumn{8}{|c|}{$\begin{array}{l}\text { Table } 4 \\
\text { Concentrations of Explosives-Related Analytes in Soil Samples from an Artillery and } \\
\text { Mortar Testing Range }\end{array}$} \\
\hline \multirow{2}{*}{$\begin{array}{l}\text { Sampling } \\
\text { Locale }\end{array}$} & \multirow[b]{2}{*}{ Soil Sample } & \multicolumn{6}{|c|}{ Concentration (mg/kg) } \\
\hline & & $2,4,6-T N T$ & TNB & 2,4-DNT & 4-ADNT & 2-ADNT & 1,3-DNB \\
\hline \multirow[t]{2}{*}{ 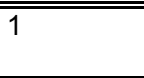 } & $\begin{array}{l}\text { Unexploded } 155-\mathrm{mm}-1 \\
\end{array}$ & 7.5 & $<<\mathrm{d}$ & 0.3 & 0.1 & 0.03 & 0.5 \\
\hline & Unexploded 155-mm-2 & 0.05 & $<d$ & $<\mathrm{d}$ & $<d$ & $<d$ & $<\mathrm{d}$ \\
\hline \multirow[t]{2}{*}{2} & Unexploded 155-mm-3 & 0.02 & $<d$ & $<d$ & 0.008 & $<d$ & $<\mathrm{d}$ \\
\hline & Unexploded 155-mm-4 & $<\mathrm{d}$ & $<d$ & $<d$ & $<d$ & $<d$ & $<d$ \\
\hline \multirow[t]{2}{*}{3} & 155-mm detonation crater-1 & 3.8 & $<\mathrm{d}^{*}$ & 0.02 & 0.09 & 0.08 & $<\mathrm{d}$ \\
\hline & 155-mm detonation crater-2 & 0.06 & $<d$ & $<d$ & 0.01 & $<d$ & $<\mathrm{d}$ \\
\hline \multirow[t]{2}{*}{4} & 155-mm detonation crater-3 & 0.05 & $<\mathrm{d}$ & $<\mathrm{d}$ & $<\mathrm{d}$ & $<d$ & $<\mathrm{d}$ \\
\hline & 155-mm detonation crater-4 & 0.10 & $<\mathrm{d}$ & $<\mathrm{d}$ & 0.002 & $<d$ & $<\mathrm{d}$ \\
\hline \multirow[t]{2}{*}{5} & 155-mm low-order-1 & 6500 & 1.8 & 11 & 72 & 79 & 4.6 \\
\hline & 155-mm low-order-2 & 4400 & 1.0 & 7.9 & 49 & 61 & 4.3 \\
\hline \multirow[t]{2}{*}{6} & 81-mm mortar crater-1 & 0.02 & $<d$ & $<\mathrm{d}$ & 0.02 & $<d$ & $<d$ \\
\hline & 81-mm mortar crater-2 & $<\mathrm{d}$ & $<\mathrm{d}$ & $<\mathrm{d}$ & $<\mathrm{d}$ & $<\mathrm{d}$ & $<\mathrm{d}$ \\
\hline \multirow[t]{2}{*}{7} & 60-mm mortar crater-1 & $<\mathrm{d}$ & $<\mathrm{d}$ & $<\mathrm{d}$ & $<\mathrm{d}$ & $<\mathrm{d}$ & $<\mathrm{d}$ \\
\hline & $60-\mathrm{mm}$ mortar crater-2 & $<\mathrm{d}$ & $<\mathrm{d}$ & $<\mathrm{d}$ & $<\mathrm{d}$ & $<\mathrm{d}$ & $<\mathrm{d}$ \\
\hline \multirow[t]{2}{*}{8} & Range background soil-1 & $<\mathrm{d}$ & $<\mathrm{d}$ & $<\mathrm{d}$ & $<\mathrm{d}$ & $<d$ & $<\mathrm{d}$ \\
\hline & Range background soil-2 & $<d$ & $<d$ & $<d$ & $<d$ & $<d$ & $<d$ \\
\hline
\end{tabular}

Concentrations of explosives residues found next to the low-order round (locale 5) were very high (Table 4). Soil concentrations of TNT were greater than $4,400 \mathrm{mg} / \mathrm{kg}$. Easily detectable concentrations of manufacturing impurities (2,4-DNT and 1,3-DNB) and TNT transformation products (1,3,5-TNB, 4-ADNT, and 2-ADNT) were also found for these two samples. This low-order detonation did not occur during a firing event, but during an attempt to detonate the munition with $\mathrm{C} 4$. Nevertheless, when an HE round is breached, concentrations of soil residues can reach high levels.

One of the two soil samples from the $81-\mathrm{mm}$ mortar detonation crater (locale 6) contained low levels of TNT $(0.02 \mathrm{mg} / \mathrm{kg})$. This concentration was detectable with the new GC-ECD method, but that would have been below detection limits if the most widely used soil analysis method (SW846 Method 8330 (USEPA 1994)) had been used. No detectable explosive residues were present in the soils from the $60-\mathrm{mm}$ mortar detonation crater (locale 7). No explosive residues were detected in the two soil samples collected to represent the general level of background contamination on the range (locale 8).

These preliminary results suggest that explosives residues are present in the surface soils at artillery and mortar testing ranges. However, levels are likely to be low, except where breached rounds are present. Therefore, breached munitions provide the greatest potential source for soil contamination. 


\section{Conclusions}

Range clearance operations generally result in recovery and identification of a wide variety of munitions, both modern and obsolete. Estimates of munitions integrity can be based upon (a) firing range physical surveys; (b) dud rates; (c) low-order detonation rates; (d) degree of corrosion; and (e) number of cracked and broken shell casings. Determining the distribution and density of UXO on a firing range is a difficult exercise. Estimates of ordnance density and distribution obtained during the explosives safety exposure assessment are an important source of information for UXO source term modules. The Unexploded Ordnance Density Calculator appears to be an effective means for linking density and distribution estimates to the source term module for UXO fate and transport evaluation. Concentration of explosives can be determined by composite sampling and using field and refined laboratory analytical chemical methods. Detection of explosives residues at artillery and mortar ranges will require low detection limit laboratory methods. Sampling and analysis of explosive concentrations in firing range soils showed that concentrations were highest next to a munition that had undergone a low-order detonation during a disposal attempt. Concentrations of explosives were generally low in detonation craters and adjacent to intact munitions. These results suggest that explosives residues are likely to be low except when low-order or breached munitions are present. 


\section{References}

Brannon, J. M., and Myers, T. E. (1997). "Review of fate and transport processes of explosives," Technical Report IRRP-97-2, U.S. Army Engineer Waterways Experiment Station, Vicksburg, MS.

Brannon, J. M., Deliman, P. N., Gerald, J. A., Ruiz, C., Price, C. B., Hayes, C., Yost, S., and Qasim, M. (1999). "Conceptual model and process descriptor formulations for fate and transport of UXO," Technical Report IRRP-99-1, U.S. Army Engineer Waterways Experiment Station, Vicksburg, MS.

Conley, J. H., Hughes, J., Stolarz, A., Pritchard, P., and Wampler, S. (1997). "Report of firing records search. 75-MM, 105-MM, and 155-MM caliber weapon at Aberdeen Proving Ground, Maryland," U.S. Army Aberdeen Test Center, Aberdeen Proving Ground, MD.

Darrach, M. R., Chutfian, A., and Plett, G. A. (1998). "Trace explosives signatures from World War II unexploded undersea ordnance." Environmental Science and Technology 32, 1354-1358.

Fauth, M. I. (1988). "Determination of the fate of fragmented or unexploded munitions and munitions ingredients in the environment - A literature search," Naval Explosive Ordnance Disposal Technology Center (NAVEODTECHCEN) Technical Report TR-282, Indian Head, MD.

Hewitt, A. D., and Jenkins, T. F. (1999). "On-site method for nitroaromatic and nitramine explosives in soil and groundwater using GC-NPD," CRREL Special Report 99-9, USA Cold Regions Research and Engineering Laboratory, Hanover, NH.

Jenkins, T. F., Grant, C. L., Brar, G. S., Thorne, P. G., Schumacher, P. W., and Ranney, T. A. (1997a). "Assessment of sampling error associated with the collection and analysis of soil samples at explosives contaminated sites," Field Analytical Chemistry and Technology 1, 151-163.

Jenkins, T. F., Walsh, M. E., Thorne, P. G., Thiboutot, S., Ampleman, G., Ranney, T. A., and Grant, C. L. (1997b). "Assessment of sampling error associated with collection and analysis of soil samples at a firing range contaminated with HMX," CRREL Report 97-22, USA Cold Regions Research and Engineering Laboratory, Hanover, NH. 
Jenkins, T. F., Walsh, M. E., Thorne, P. G., Miyares, P. H., Ranney, T. A., Grant, C. L., and Esparza, J. R. (1998). "Site characterization at the inland firing range impact area at Fort Ord," CRREL Report 98-9, USA Cold Regions Research and Engineering Laboratory, Hanover, NH.

Jenkins, T. F., Grant, C. L., Walsh, M. E., Thorne, P. G., Thiboutot, S., Ampleman, G., and Ranney T. A. (1999). "Coping with spatial heterogeneity effects on sampling and analysis at an HMX - contaminated antitank firing range," Field Analytical Chemistry and Technology 3(1), 1928

McGrath, C. J. (1995). "Review of formulations for processes affecting the subsurface transport of explosives," Technical Report IRRP-95-2, U.S. Army Engineer Waterways Experiment Station, Vicksburg, MS.

McNeil, M. B., and Odom, A. L. (1992). "Thermodynamic prediction of microbiologically influenced corrosion (MIC) by sulfate-reducing bacteria (SRB)," in "Microbiologically Influenced Corrosion Testing," J. R. Kearns and B. J. Little, ed., American Society for Testing and Materials, Philadelphia, PA, 173-179.

Owens, H. (1999). “UXO Modeling.” The Military Engineer 91(601), 61-62.

Thiboutot, S., Ampleman, G., Gagnon, A., Marois, A., Jenkins, T. F., Walsh, M. E., Thorne, P. G., and Ranney, T. A. (1998). "Characterization of antitank firing ranges at CFB Valcartier, WATC Wainwright and CFAD Dundurn," DREV-R-9809, Research and Development Branch, Department of National Defence Canada.

Townsend, D. M., and Myers, T. E. (1996). "Recent developments in formulating model descriptors for subsurface transformation and sorption of TNT, RDX, and HMX," Technical Report IRRP-96-1, U.S. Army Engineer Waterways Experiment Station, Vicksburg, MS.

U.S. Environmental Protection Agency. (1994). "Nitroaromatics and nitramines by HPLC," Second Update, SW846 Method 8330, Washington, DC.

. (1996). "Screening method for TNT in soil," Third Update

SW 846 Method 8515, Washington, DC.

. "Nitroaromatics and Nitramines by GC-ECD," (in preparation), Fourth Update SW 846 Method 8095, Washington, DC.

. "Screening method for RDX in soil," (in preparation), Fourth Update SW 846 Method 8510, Washington, DC.

Walsh, M. E., Jenkins, T. F., Schnitker, P. S., Elwell, J. W., and Stutz, M. H. (1993). "Evaluation of SW846 Method 8330 for characterization of sites contaminated with residues of high explosives," CRREL Report 93-5, USA Cold Regions Research and Engineering Laboratory, Hanover, NH. 
Walsh, M. E., and Ranney, T. A. (1999). "Determination of nitroaromatic, nitramine, and nitrate ester explosives in soils by gas chromatography electron capture detection," CRREL Special Report 99-12, USA Cold Regions Research and Engineering Laboratory, Hanover, NH. 


\section{Appendix A Assessment of Fort Ord Data}

The Fort Ord, California, database contained the following information on recovered ordnance: location (which includes the site number, parcel, number, and depth), team number, date the ordnance was found, ordnance type, quantity, whether the device was live or inert, and it's disposition.

In all, 26,246 ordnance items and another 1,345.75 pounds of fragments were reported. Ordnance items were categorized using the classification scheme used in the Army Ammunition Data Sheets (Headquarters, Department of the Army 1994a-f). Table A1 provides the total number of each ordnance type and the pounds of fragments recovered. This list also includes 246 miscellaneous ordnance items (and $282 \mathrm{lb}$ of fragments) for which descriptive data were unavailable. The database also contained 540 items that were too badly deteriorated to be identifiable. These items were categorized as unknown ordnance. The most prevalent type of ordnance found were mortar ammunition, fuzes, small caliber ammunition, and grenades. These four types of ordnance accounted for 84 percent of the total items recovered (22,113 items).

Table A2 lists commonly found individual ordnance (i.e., where 20 or more items were found). For each item, the quantity found and the percentage of live items are given. The most commonly reported munitions were the 22-mm subcaliber M744 practice mortar, the 14.5-mm M18A1 cartridge, and the M228 and M204 hand grenade fuzes (Table A3). These four items accounted for 69 percent $(18,099)$ of the total items found(Table A3).

These data indicate that firing ranges contain a wide variety of munition types because of the varied uses of the ranges. The information commonly obtained during cleanup operations does not include information on the condition of the recovered munitions other than percent live. The percentage of live munitions found is highly variable, depending upon the specific item found, and varies from 0 to 100 percent. 


\section{References}

Headquarters, Department of the Army. (1981). "Army ammunition data sheets for rockets, rocket systems, rocket fuzes, rocket motors (Federal Supply Class 1340)," Technical Manual No. 43-0001-30, Washington, DC.

Headquarters, Department of the Army. (1994a). "Army ammunition data sheets for small caliber ammunition (FSC 1305)," Technical Manual No. 430001-27, Washington, DC.

Headquarters, Department of the Army. (1994b). "Army ammunition data sheets for artillery ammunition: Guns, howitzers, mortars, recoiless rifles, grenade launchers, and artillery fuzes," Technical Manual No. 43-0001-28, Washington, DC.

Headquarters, Department of the Army. (1994c). "Army ammunition data sheets for grenades," Technical Manual No. 43-0001-29, Washington, DC.

Headquarters, Department of the Army. (1994d). "Army ammunition data sheets (Land mines (FSC 1345),” Technical Manual No. 43-0001-36, Washington, DC.

Headquarters, Department of the Army. (1994e). "Army ammunition data sheets: Military pyrotechnics (Federal supply class 1370)," Technical Manual No. 43-0001-37, Washington, DC.

Headquarters, Department of the Army. (1994f). "Army ammunition data sheets for demolition materials," Technical Manual No. 43-0001-38, Washington, DC. 


\begin{tabular}{|c|c|c|}
\hline \multicolumn{3}{|c|}{$\begin{array}{l}\text { Table A1 } \\
\text { Total Number of Each Ordnance Type and Pounds of Fragments } \\
\text { Recovered }\end{array}$} \\
\hline \multicolumn{3}{|c|}{$\begin{array}{l}\text { Total \# ordnance = 26,246 } \\
\text { Total \# lb Fragments = 1,345.75 }\end{array}$} \\
\hline Type & \# ordnance/ea & Fragments, Ib \\
\hline Demolition materials & 578 & \\
\hline Fuzes & 5,339 & \\
\hline Grenade launcher ammo & 157 & \\
\hline Grenades & 1,372 & 660 \\
\hline Artillery ammunition for guns & 71 & 5.75 \\
\hline Howitzers & 60 & \\
\hline Mines & 469 & \\
\hline Mine activators & 4 & \\
\hline Misc. U.S. & 257 & 282 \\
\hline Misc. Foreign & 9 & \\
\hline Mortar & 10,593 & 17 \\
\hline Recoiless rifle ammunition & 31 & \\
\hline Rockets & 931 & 135 \\
\hline Rocket motors & 27 & \\
\hline Signals - illumination & 602 & \\
\hline Signals - other & 63 & \\
\hline Signals - slap flares & 11 & \\
\hline Signals - flares & 152 & \\
\hline Simulators & 171 & \\
\hline Small caliber ammunition & 4,809 & \\
\hline Unknown & 540 & 246 \\
\hline Totals & 26,246 & $1,345.75$ \\
\hline
\end{tabular}




\begin{tabular}{|c|c|c|c|c|}
\hline \multicolumn{5}{|c|}{$\begin{array}{l}\text { Table A2 } \\
\text { Commonly Found Ordance by Type }{ }^{1}\end{array}$} \\
\hline $\begin{array}{l}\text { Type of } \\
\text { Ordnance }\end{array}$ & $\begin{array}{l}\text { Quantity } \\
\text { Found }\end{array}$ & Fragment, lb & Specific Ordnance & Percent Live \\
\hline \multirow[t]{10}{*}{ Mortars } & 9,261 & & Ctg., 22-mm subcaliber, practice M744 & 99.8 \\
\hline & 289 & & Proj., 81-mm, HE, M43 & 95 \\
\hline & 238 & & Proj., 3-in. Stokes (trench mortar), practice, MK1 & 16 \\
\hline & 231 & & Proj., 81-mm, training, M68 & 0.4 \\
\hline & 181 & & Proj., 81-mm, TP, M43 type & 94 \\
\hline & 114 & & Ignition cartridge, M2 type & 10 \\
\hline & 83 & & Proj., 4.2-in., smoke, WP, M328 type & 0 \\
\hline & 65 & & Proj., 60-mm, HE, M49 type & 88 \\
\hline & 28 & & Proj., 60-mm, TP, M50 type & 68 \\
\hline & 22 & & Proj., 60-mm, Illum., M721 & 64 \\
\hline \multirow{4}{*}{$\begin{array}{l}\text { Small caliber } \\
\text { ammunition }\end{array}$} & 4,485 & & Ctg., 14.5-mm, trainer spotter & 100 \\
\hline & 256 & & Ctg., 7.62-mm, blank, M63 & 100 \\
\hline & 35 & & Ctg., 5.66-mm, blank, M200 & 100 \\
\hline & 21 & & Ctg., 20-mm, target practice, M55A2 & 100 \\
\hline \multirow[t]{9}{*}{ Fuzes } & 2,615 & & Grenade, hand, practice, M228 & 15 \\
\hline & 1,770 & & Grenade, hand, M204 & 0.2 \\
\hline & 369 & & Grenade, hand, M206 type & 0.3 \\
\hline & 144 & & Projectile, point detonating, M48 series & 3 \\
\hline & 120 & & Grenade, hand, M10 series & 34 \\
\hline & 97 & & Grenade, hand, M205 type & 84 \\
\hline & 44 & & Projectile, powder train time fuze, M1907 & 20 \\
\hline & 21 & & Mine, AT, M600 series & 100 \\
\hline & 20 & & Projectile, base detonating, practice, M58 & 0 \\
\hline \multirow[t]{11}{*}{ Grenades } & 367 & & Rifle, smoke, M22 type & 5 \\
\hline & 159 & & Hand, fragmentation, MK2 type & 13 \\
\hline & 198 & & Rifle, AT, M9 type & 40 \\
\hline & 162 & & Hand, smoke, M18 & 18 \\
\hline & 128 & & Hand, Illumination, MK1 & 7 \\
\hline & 40 & & Hand, Practice, MK2 & 40 \\
\hline & 36 & & Hand, Practice, delay, M30 & 0 \\
\hline & 35 & & Hand, Riot, M7 series & 66 \\
\hline & 30 & & Hand, smoke, WP, M15 & 0 \\
\hline & 27 & & Rifle, smoke, M23 type & 30 \\
\hline & 22 & & Hand, smoke, HC, AN-M8 & 41 \\
\hline \multirow{4}{*}{$\begin{array}{l}\text { Signals - } \\
\text { Illumination }\end{array}$} & 194 & & Ground, parachute, green star M19 series & 5 \\
\hline & 175 & & $\begin{array}{l}\text { Ground, clusters, green star, M125 series, red } \\
\text { star M158, white star M159 }\end{array}$ & 19 \\
\hline & 152 & & $\begin{array}{l}\text { Ground, parachute, red star M126 series, white } \\
\text { star M127 series, green star M195 }\end{array}$ & 11 \\
\hline & 21 & & $\begin{array}{l}\text { Aircraft, single star, AN-M43A2, AN-M44A2, } \\
\text { AN-M45A2 }\end{array}$ & 43 \\
\hline \multirow[t]{2}{*}{ Signals - Flares } & 87 & & Surface, trip, M49 type & 48 \\
\hline & 60 & & Parachute, trip, M48 type & 5 \\
\hline \multirow[t]{2}{*}{ Signals - Other } & 31 & & Ground, rifle, M17A1 & 6 \\
\hline & 28 & & Flash and sound, M74 & 14 \\
\hline \multirow{4}{*}{$\begin{array}{l}\text { Demolition } \\
\text { Materials }\end{array}$} & 468 & & Caps, blasting, electric, M6 & 99 \\
\hline & 52 & & Firing device, pull, M1 & 38 \\
\hline & 36 & & Detonating cord & 100 \\
\hline & 35 & & Firing device, mouse trap, M2 & 6 \\
\hline \multirow[t]{2}{*}{ Mines } & 400 & & Replacement kits for M8, practice, antipersonnel & 100 \\
\hline & 26 & & Mine, antitank, practice, light, M1 & 85 \\
\hline \multicolumn{5}{|c|}{$\begin{array}{ll} & \text { (Continued) } \\
\end{array}$} \\
\hline
\end{tabular}




\begin{tabular}{|c|c|c|c|c|}
\hline \multicolumn{5}{|c|}{ Table A2 (Concluded) } \\
\hline $\begin{array}{l}\text { Type of } \\
\text { Ordnance }\end{array}$ & $\begin{array}{l}\text { Quantity } \\
\text { Found }\end{array}$ & Fragment, lb & Specific Ordnance & Percent Live \\
\hline \multirow[t]{5}{*}{ Rockets } & 309 & & 35-mm, subcaliber, practice, M73 & 85 \\
\hline & 282 & 135 & 3.5-in., practice, M29 type & 0.8 \\
\hline & 219 & & 2.36-in., M7 series & 66 \\
\hline & 75 & & 2.36-in., AT, M6 series & 64 \\
\hline & 32 & & 66-mm, incendiary, TPA, M74 & 97 \\
\hline Rocket Motors & 20 & & HEAT, M22 (Dragon) (for guided missile) & 100 \\
\hline Howitzers & 23 & & $\begin{array}{l}\text { Projectile, 155-mm, smoke, BE, M116 \& } \\
\text { M116B1, HC and colored }\end{array}$ & 100 \\
\hline $\begin{array}{l}\text { Artillery } \\
\text { ammunition- } \\
\text { guns }\end{array}$ & 51 & & Projectile, 27-mm, HE, M63 & 4 \\
\hline \multirow{2}{*}{$\begin{array}{l}\text { Grenade } \\
\text { launcher ammo }\end{array}$} & 64 & & 40-mm projectile, practice, M382 & 3 \\
\hline & 31 & & 40-mm projectile, practice, M781 & 19 \\
\hline \multirow[t]{3}{*}{ Simulators } & 88 & & Projectile, air burst, M74 type & 3 \\
\hline & 36 & & Rocket motors & 100 \\
\hline & 31 & & Rocket/Squib & 100 \\
\hline \multirow[t]{3}{*}{ Misc. Items } & 87 & & Projectile, 37-mm, AP-T, M51B1, M51B2 & 5 \\
\hline & 43 & & Projectile, 37-mm, LE, MK1 & 0 \\
\hline & 32 & & Projectile, 75-mm, shrapnel, MK1 & 22 \\
\hline
\end{tabular}

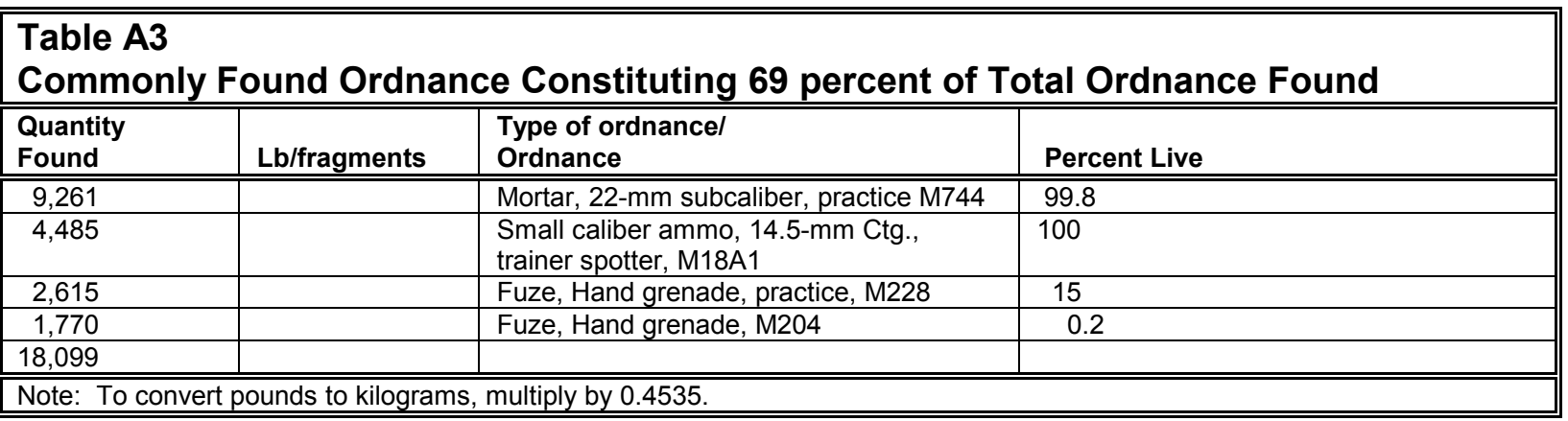




\section{Appendix B Composition of Common Munitions}

Table B1 lists the readily available composition data for munitions found at Fort Ord, California. Only the more commonly occurring munitions were included on this list, i.e., those where 100 or more were found at the Fort Ord site. Composition data are based upon information provided by the Munitions Items Disposition Action System (MIDAS). The MIDAS program is managed by Argonne National Laboratory, U.S. Army Defense Ammunition Center, Savannah Army Depot. This database contains composition information on 4,105 munitions, or approximately three-fourths of the total types of munitions found at Fort Ord (Table B1). Other potential sources of information on munition composition are provided in the Appendix A references.

Table B2 summarizes data on the total weight of each explosive component in descending order of component mass and is presented for a few of the recovered munitions as an example of the type of information available through the MIDAS program. Chemical components of the parts such as stainless steel or plastic body parts are not included in this list but can be found in the MIDAS database. For each part in a munition, the total weight of the explosive component was calculated in grams by the following formula:

$\mathrm{N} *(\mathrm{P} / 100) * \mathrm{~W}$

where

$$
\begin{aligned}
& \mathrm{N}=\text { the total number of a given munition } \\
& \mathrm{P}=\text { the percent composition of a component in a part } \\
& \mathrm{W}=\text { the weight in grams of the part }
\end{aligned}
$$

Weights of chemical components for individual ordnance items can be obtained by dividing the weight in grams in Table B2 by the total number of components. Information from other available sources, some of which are presented in the references, may not be as complete as that contained in the MIDAS database. 


\begin{tabular}{|c|c|c|c|c|}
\hline \multicolumn{5}{|c|}{$\begin{array}{l}\text { Table B1 } \\
\text { Occurrence of Composition Data for More Commonly Found Ordnance }{ }^{1}\end{array}$} \\
\hline Type of Ordnance & \# Found & $\begin{array}{l}\text { Fragments, } \\
\text { lb }\end{array}$ & Specific Ordnance & \begin{tabular}{|l|} 
Data \\
on Composition
\end{tabular} \\
\hline \multirow[t]{6}{*}{ Mortars } & 99,261 & & "Ctg., 22-mm subcaliber, practice M744 & $\mathrm{Ev}$ \\
\hline & 289 & & Proj., 81-mm, HE, M43 & - \\
\hline & 238 & & $\begin{array}{l}\text { Proj., 3-in. Stokes (trench mortar), practice, } \\
\text { MK1 }\end{array}$ & - \\
\hline & 231 & & Proj., 81-mm, training, M68 & - \\
\hline & 181 & & Proj., 81-mm, TP, M43 type & $\checkmark$ \\
\hline & 114 & & Ignition cartridge, M2 type & $\checkmark$ \\
\hline \multirow{2}{*}{$\begin{array}{l}\text { Small caliber } \\
\text { ammunition }\end{array}$} & 4,485 & & Ctg., 14.5-mm, trainer spotter & $\mathrm{v}$ \\
\hline & 256 & & Ctg., 7.62-mm, blank, M63 & $\checkmark$ \\
\hline \multirow[t]{5}{*}{ Fuzes } & 2,615 & & Grenade, hand, practice, M228 & - \\
\hline & 1,770 & & Grenade, hand, M204 & $\checkmark$ \\
\hline & 369 & & Grenade, hand, M206 type & $\checkmark$ \\
\hline & 144 & & Projectile, point detonating, M48 series & $\checkmark$ \\
\hline & 120 & & Grenade, hand, M10 series & - \\
\hline \multirow[t]{5}{*}{ Grenades } & 367 & & Rifle, smoke, M22 type & $\checkmark$ \\
\hline & 159 & & Hand, fragmentation, MK2 type & - \\
\hline & 198 & & Rifle, AT, M9 type & - \\
\hline & 162 & & Hand, smoke, M18 & $\checkmark$ \\
\hline & 128 & & Hand, Illumination, MK1 & - \\
\hline \multirow[t]{3}{*}{ Signals - Illumination } & 194 & & Ground, parachute, green star M19 series & - \\
\hline & 175 & & $\begin{array}{l}\text { Ground, clusters, green star, M125 series, red } \\
\text { star M158, white star M159 }\end{array}$ & $\checkmark$ \\
\hline & 152 & & $\begin{array}{l}\text { Ground, parachute, red star M126 series, white } \\
\text { star M127 series, green star M195 }\end{array}$ & $\checkmark$ \\
\hline Demolition Materials & 468 & & Caps, blasting, electric, M6 & $\checkmark$ \\
\hline Mines & 400 & & $\begin{array}{l}\text { Replacement kits for M8, practice, anti- } \\
\text { personnel }\end{array}$ & $\vee$ \\
\hline \multirow[t]{3}{*}{ Rockets } & 309 & & 35-mm, subcaliber, practice, M73 & $\checkmark$ \\
\hline & 282 & 135 & 3.5-in., practice, M29 type & $\checkmark$ \\
\hline & 219 & & 2.36-in., M7 series & - \\
\hline
\end{tabular}




\section{Table B2 \\ Type of Information Available in MIDAS Database. (Quantity, type, components, and weight of components contained in a few representative munitions recovered at Fort Ord, California)}

\begin{tabular}{|c|c|c|c|}
\hline Quantity & Munition & Components & Total WT, grams \\
\hline \multirow[t]{15}{*}{9,261} & \multirow[t]{15}{*}{ M744, 22-mm subcaliber Cartridge, practice } & K chlorate & $36,117.9$ \\
\hline & & Al powder & $23,337.7$ \\
\hline & & K perchlorate & $23,337.7$ \\
\hline & & CD & $18,151.6$ \\
\hline & & Ca silicide & $9,724.1$ \\
\hline & & Glass & $9,724.1$ \\
\hline & & Sb sulfide & $9,724.1$ \\
\hline & & Tetracene & $8,334.9$ \\
\hline & & NC (N 12.8 percent) & $8,154.3$ \\
\hline & & K nitrate & $5,556.6$ \\
\hline & & Nitroglycerine & $5,556.6$ \\
\hline & & Charcoal & $1,111.3$ \\
\hline & & $S$ & 740.9 \\
\hline & & Diphenylamine & 138.9 \\
\hline & & Vaseline & 41.7 \\
\hline \multirow[t]{25}{*}{4,485} & \multirow[t]{25}{*}{ M18A1 14.5-mm Cartridge, trainer spotter } & $\mathrm{Pb}$ dioxide & $17,801.0$ \\
\hline & & Sr nitrate & $16,275.2$ \\
\hline & & Mg Powder & $7,265.7$ \\
\hline & & $\mathrm{Pb}$ powder & $7,265.7$ \\
\hline & & PVC & $5,521.9$ \\
\hline & & Mg-Al & $3,705.5$ \\
\hline & & $\overline{N C}$ & 548.5 \\
\hline & & Pb Styphanate & 330.4 \\
\hline & & Ca phosphate & 290.6 \\
\hline & & Nitroglycerine & 244.1 \\
\hline & & Ba nitrate & 200.0 \\
\hline & & Sr peroxide & 176.6 \\
\hline & & $\mathrm{Zr}$ & 155.8 \\
\hline & & Fe Oxide Red & 59.9 \\
\hline & & Ca silicide & 44.8 \\
\hline & & Diatomaceous Earth & 24.0 \\
\hline & & Sb sulfide & 20.2 \\
\hline & & Ca resinate & 19.6 \\
\hline & & Ethyl Centralite & 12.2 \\
\hline & & Al powder & 11.8 \\
\hline & & Tetracene & 6.7 \\
\hline & & Graphite & 4.1 \\
\hline & & K nitrate & 4.1 \\
\hline & & Acrylic polymer & 2.2 \\
\hline & & Ethyl alcohol & 0.8 \\
\hline
\end{tabular}




\begin{tabular}{|c|c|c|c|}
\hline \multicolumn{4}{|c|}{ Table B2 (Concluded) } \\
\hline Quantity & Munition & Components & Total Wt, grams \\
\hline \multirow[t]{11}{*}{1,770} & \multirow[t]{11}{*}{ M204 Fuze, Hand Grenade } & RDX & $1,517.4$ \\
\hline & & Ba chromate & $1,376.4$ \\
\hline & & Zr-Ni Alloy & 596.4 \\
\hline & & Pb azide (100 percent) & 458.8 \\
\hline & & K perchlorate & 321.1 \\
\hline & & Pb styphnate & 134.8 \\
\hline & & Graphite & 31.0 \\
\hline & & Ba nitrate & 8.3 \\
\hline & & Al powder & 3.8 \\
\hline & & Sb sulfide & 3.8 \\
\hline & & Tetracene & 1.9 \\
\hline \multirow[t]{5}{*}{408} & \multirow[t]{5}{*}{ M6 Blasting Caps, Electric } & RDX (100 percent) & 383.4 \\
\hline & & $\mathrm{Pb}$ azide (100 percent) & 110.2 \\
\hline & & Smokeless powder & 23.8 \\
\hline & & K chlorate & 11.9 \\
\hline & & $\mathrm{Pb}-\mathrm{Na}$ Dinitro Ortho & 11.9 \\
\hline \multirow[t]{15}{*}{181} & \multirow[t]{15}{*}{ M43A1 TP 81-mm Mortar, with PD fuze } & Tetryl (100 percent) & $3,110.8$ \\
\hline & & Na nitrate & $2,955.6$ \\
\hline & & $\overline{\mathrm{NC}}$ & $1,545.2$ \\
\hline & & Nitroglycerin & $1,167.1$ \\
\hline & & Charcoal & 680.3 \\
\hline & & $S$ & 474.1 \\
\hline & & K nitrate & 53.1 \\
\hline & & Diethylphthalate & 41.2 \\
\hline & & $\mathrm{Pb}$ azide & 33.9 \\
\hline & & Ethyl Centralite & 19.1 \\
\hline & & K chlorate & 6.1 \\
\hline & & Sb sulfide & 4.5 \\
\hline & & $\mathrm{Pb}$ thiocyanate & 1.1 \\
\hline & & Carborundum & 0.6 \\
\hline & & TNT & 0.2 \\
\hline
\end{tabular}




\section{Appendix C Effects of Steel on Soluble TNT, RDX, and HMX}

\section{Introduction}

Recent studies have shown that zero valent iron $^{1,2}$ and reduced iron $^{3}$ can strongly impact the fate and transport of explosives. TNT exposed to zero valent iron disappears from solution rapidly as does RDX and HMX, although apparently at a lower rate. ${ }^{1}$ TNT is rapidly removed from solution by reduced iron in the presence of a sorbing surface. ${ }^{3}$ The reduction processes that were observed for zero valent iron and reduced iron should be operative for explosives exiting corroded UXO under anaerobic conditions. These processes should act to reduce the flux of primary explosives from fractured munitions, possibly producing transformation products that are susceptible to microbial mineralization or sequestration by soil and sediment organic matter or minerals. The objective of this study was to determine the effects of common steel on TNT, RDX, and HMX.

\section{Materials and Methods}

Common steel powder obtained from the Hoeganaes Corporation, Riverton, NJ. Separate solutions of TNT (50 mg/L), RDX (29 mg/L), and HMX (3 mg/L) dissolved in distilled water were purged with nitrogen to remove oxygen, then sealed and placed in a glove box under a nitrogen atmosphere. Fifteen milliters of the explosives solution was then added to $15-\mathrm{ml}$ volatile organic analysis (VOA) vials. Sufficient VOA vials were prepared to enable duplicate determinations at each time interval. To each of the VOA vials containing explosives

\footnotetext{
${ }^{1}$ Personal communication, 2 September 1999, Chris McGrath, Research Physical Scientist, U.S. Army Engineer Waterways Experiment Station, Vicksburg, MS.

${ }^{2}$ J. Singh, S. D. Comfort, and P. J. Shea. (1998). "Remediating RDX-contaminated water and soil using zero-valent iron," Journal of Environmental Quality 27, 1240-1245. ${ }^{3}$ J. M. Brannon, C. B. Price, and C. Hayes. (1998). "Abiotic transformation of TNT in montmorillonite and soil suspensions under reducing conditions," Chemosphere 36, 1453-1462.
} 
solution, $0.5 \mathrm{~g}$ of steel powder that had been kept under nitrogen in the glove box was added and the vials sealed. One set of duplicates was sampled immediately $(1 \mathrm{~min})$ and the remaining sets were placed in a rotary shaker and agitated at 32 revolutions per minute until the appointed sampling time $(0.25,0.5,1,1.5,2$, 6 , and $24 \mathrm{hr}$ ). After sampling, the solution was poured into a syringe filter and pressure filtered through a $0.5-\mu \mathrm{m}$ membrane filter. The filtrate was analyzed for explosives according to EPA method 8330. ${ }^{1}$ Tests were conducted at $25^{\circ} \mathrm{C}$.

\section{Results and Discussion}

Common steel rapidly removed TNT, RDX, and HMX from solution (Figure $\mathrm{C} 1$ ). The times required for removal were on the order TNT $<\mathrm{RDX}<$ HMX. Processes that removed explosives contaminants from solution can be approximated with first-order kinetics which take the form

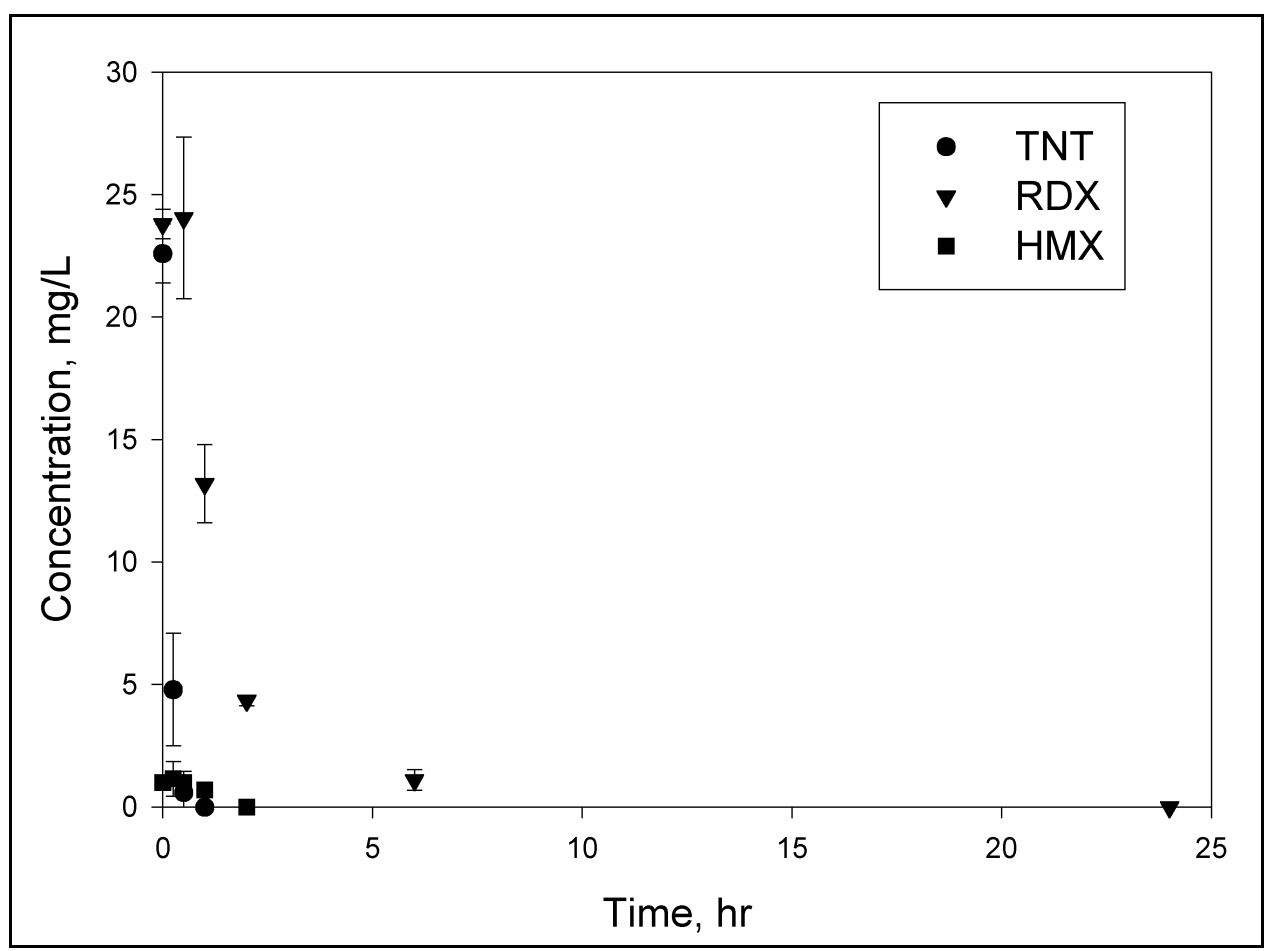

Figure C1. Effect of steel on TNT, RDX, and HMX solution concentrations

\footnotetext{
${ }^{1}$ U.S. Environmental Protection Agency. (1994). "Nitroaromatics and nitramines by HPLC," Second Update, SW846 Method 8330, Washington, DC.
} 
(1)

$\mathrm{dc} / \mathrm{dt}=-\mathrm{kc}$

where

$\mathrm{c}=$ chemical concentration of the reacting substance, $\mathrm{mg} / \mathrm{L}$

$\mathrm{k}=$ first-order reaction constant, $\mathrm{hr}^{-1}$

$\mathrm{t}=$ time, $\mathrm{hr}$

First-order kinetics reduces to the equation

$$
\ln \left(\mathrm{c}_{0} / \mathrm{c}\right)=\mathrm{kt}
$$

where $\mathrm{c}_{0}$ is the concentration of the reacting substance at time 0 .

Once a value of $\mathrm{k}$ is obtained, the half-life period of the reacting substance, $\mathrm{t}_{1 / 2}$, can be calculated using the equation

$$
\mathrm{t}_{1 / 2}=0.693 / \mathrm{k}
$$

First-order kinetics described the disappearance of explosives in the presence of steel (Table C1). Reaction rate constants were high, resulting in half-lives ranging from $0.1 \mathrm{hr}$ for TNT to $1.6 \mathrm{hr}$ for HMX. These results indicate that under anaerobic conditions, common steel is capable of rapidly decreasing explosives concentrations in water. Where steel surfaces are available and environmental conditions are conducive, explosives leaking from breached munitions may be removed from solution before they can enter the environment. The limiting factor for this process is the availability of steel surfaces. The action of steel on explosives indicates that research examining the effects of zero

\begin{tabular}{|c|c|c|c|}
\hline \multicolumn{4}{|c|}{$\begin{array}{l}\text { Table C1 } \\
\text { First-Order Rate Coefficients }\left(\mathrm{K}^{-1}, \mathrm{hr}^{-1}\right) \text { and Half-Lives }\left(\mathrm{t}_{1 / 2}, \mathrm{hr}\right) \text { for } \\
\text { TNT, RDX, and HMX Exposed to Steel }\end{array}$} \\
\hline Explosive Compound & $\mathrm{K}^{-1}, \mathrm{hr}^{-1}$ & $\overline{r^{2}}$ & $\mathrm{t}_{1 / 2}, \mathrm{hr}$ \\
\hline TTNT & 6.18 & 0.96 & 0.1 \\
\hline RDX & 0.54 & \begin{tabular}{|l|l|}
0.92 \\
\end{tabular} & \begin{tabular}{|l|l|}
1.3 \\
\end{tabular} \\
\hline HMX & 0.43 & \begin{tabular}{|l|}
0.65 \\
\end{tabular} & 1.6 \\
\hline
\end{tabular}
valent iron on explosives will be relevant to steel. 


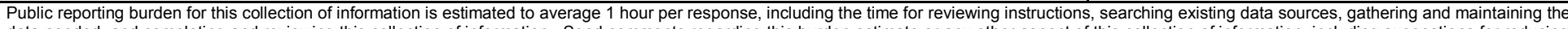

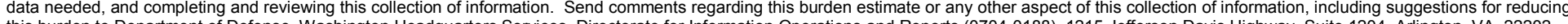

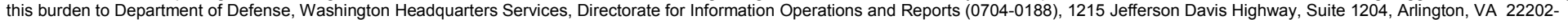

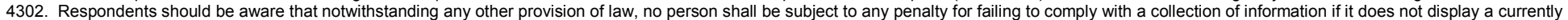
valid OMB control number. PLEASE DO NOT RETURN YOUR FORM TO THE ABOVE ADDRESS.

\begin{tabular}{|l|l|l} 
1. REPORT DATE (DD-MM-YYYY) & 2. REPORT TYPE & 3. DATES COVERED (FrOm - To)
\end{tabular}

July 2000

\section{TITLE AND SUBTITLE}

Final Report

Procedures for Determining Integrity of UXO and Explosives

Soil Contamination at Firing Ranges

5a. CONTRACT NUMBER

\section{AUTHOR(S)}

James M. Brannon, Thomas F. Jenkins, Louise V. Parker, Patrick Deliman, Jeffrey A. Gerald, Carlos Ruiz, Beth Porter, William M. Davis

5b. GRANT NUMBER

5c. PROGRAM ELEMENT NUMBER

5d. PROJECT NUMBER

5e. TASK NUMBER

5f. WORK UNIT NUMBER

\section{PERFORMING ORGANIZATION NAME(S) AND ADDRESS(ES)}

U.S. Army Engineer Research and Development Center Environmental Laboratory

3909 Halls Ferry Road

ASCI Corporation 1365 Beverly Road McLean, VA 22101
8. PERFORMING ORGANIZATION REPORT NUMBER

ERDC TR-00-4

Vicksburg, MS 39180-6199

U.S. Army Engineer Research and Development Center Cold Regions Research and Engineering Laboratory 72 Lyme Road

Hanover, NH 03755-1290

9. SPONSORING / MONITORING AGENCY NAME(S) AND ADDRESS(ES)

Headquarters, U.S. Army Corps of Engineers

Washington, DC 20314-1000

10. SPONSOR/MONITOR'S ACRONYM(S)

11. SPONSOR/MONITOR'S REPORT NUMBER(S)

\section{DISTRIBUTION / AVAILABILITY STATEMENT}

Approved for public release; distribution is unlimited.

\section{SUPPLEMENTARY NOTES}

\section{ABSTRACT}

Range clearance operations generally results in recovery and identification of a wide variety of munitions, both modern and obsolete. Estimates of munitions integrity can be based upon: a) firing range physical surveys, b) dud rates, c) low-order detonation rates, d) degree of corrosion, and e) number of cracked and broken shell casings. Determining the distribution and density of UXO on a firing range is a difficult exercise. Estimates of ordnance density and distribution obtained during the explosives safety exposure assessment are an important source of information for UXO source term modules. The Unexploded Ordnance Density Calculator appears to be an effective means for linking density and distribution estimates to the source term module for UXO fate and transport evaluation. Concentration of explosives can be determined by composite sampling and using field and refined laboratory analytical chemical methods. Detection of explosives residues at artillery and mortar ranges will require low-detection-limit laboratory methods. Sampling and analysis of explosive concentrations in firing range soils showed that concentrations were highest next to a munition that had undergone a low-order detonation during a disposal attempt. Concentrations of explosives were generally low in detonation craters and adjacent to intact munitions. These results suggest that explosives residues are likely to be low except when low-order or breached munitions are present.

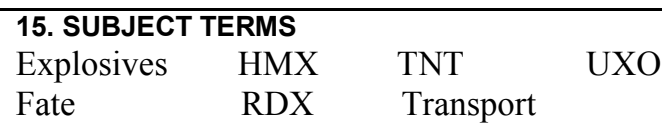

16. SECURITY CLASSIFICATION OF:

\begin{tabular}{l|l|l}
\hline a. REPORT & b. ABSTRACT & c. THIS PAGE \\
UNCLASSIFIED & & UNCLASSIFIED
\end{tabular}
OF ABSTRACT

\begin{tabular}{|c|c|}
\hline 18. NUMBER & 19a. NAME OF RESPONSIBLE PERSON \\
\hline 37 & $\begin{array}{l}\text { 19b. TELEPHONE NUMBER (include area } \\
\text { code) }\end{array}$ \\
\hline
\end{tabular}


Destroy this report when no longer needed. Do not return it to the originator. 